\title{
mpe South-South Trade in Manufactures: Current Performance and Obstacles for Growth
}

\author{
OMAR S. DAHI \\ School of Social Science, Hampshire College, Amherst, MA 01002; \\ e-mail: odahi@hampshire.edu \\ FIRAT DEMIR \\ Department of Economics, University of Oklahoma, Norman, OK 73019; \\ e-mail:fdemir@ou.edu
}

\begin{abstract}
The last two decades have witnessed resurgence in South-South trade, investment, and regional integration. This article examines trade performance in total and technology-and-skill-intensive manufactures for a sample of twenty-eight developing countries with both developed (South-North) and other developing (South-South) countries. Previous studies and our sample data show that South-South trade in manufactures is characterized by higher capital and skill-intensive factor content relative to SouthNorth trade, with major implications for development in the South, including the possibility of dynamic gains through learning by exporting, technological externalities, allocative efficiencies, and scale economies. The article concludes by discussing obstacles to increasing South-South trade and possibilities for future research on the topic.
\end{abstract}

JEL classification: F13, F14, F54, O19, O33

Keywords: South-South trade; industrial development

\section{Introduction}

Ever since the Delhi conference of 1947 and the Bandung Declaration of 1955, economic and political cooperation among the developing countries of the South has been viewed as a potential counter-hegemonic movement with the various goals of restructuring the international politico-economic order (Prashad 2006; Wardaya 2005), increasing the bargaining

Authors' Note: We thank Amitava K. Dutt, session participants at URPE at ASSA 2008 meetings in New Orleans, and the editor and two referees of the journal for their constructive comments. A detailed version of the article is available at http://faculty-staff.ou.edu/D/Firat .Demir-1/. Corresponding author's telephone: (405) 3255844.

Review of Radical Political Economics, Volume 40, No. 3, Summer 2008, 266-275

DOI: $10.1177 / 0486613408320007$

(C) 2008 Union for Radical Political Economics 
power of developing countries (Morphet 2004), and blocking or advancing issues in multinational institutions, including the United Nations (like 1988), World Bank, IMF (Sridharan 1998), and more recently, the World Trade Organization (WTO) (Narlikar and Wilkinson 2004; Narlikar 2006). In its heyday in the early 1970s, the nonaligned movement was able to produce a series of sweeping global economic restructuring suggestions (New International Economic Order) that included institutionalized commodity price stabilization controls, North-South (N-S) and South-South (S-S) technology transfer, and industrial coordination within the global South (De Silva 1983). However, with the debt crisis and the relative decline of bargaining power of the global South, these fell by the wayside. Moreover, various regional integration schemes (not to mention larger alternative Southern institutions, such as the G-15) were widely viewed as having failed for, among other reasons, incompatibility of the political and economic agendas of developing countries (Orlov 2002; Sridharan 1998; Willets 1978).

\section{S-S Trade Literature}

Within the international trade literature, S-S trade has long been pointed to as an untapped potential for developing countries. Accordingly, the research on $\mathrm{S}-\mathrm{S}$ trade can be divided into three waves. The first wave stressed S-S trade and integration as a means of overcoming market size and resource bottlenecks on the road to industrialization or as a means for reducing dependence on Northern growth and markets (Myrdal 1956; Lewis 1980). ${ }^{1}$ The second wave of studies, on the other hand, responded to the increasingly industrialized nature of S-S trade with a higher capital and skill-intensive factor content compared to the South-North (S-N) trade (Figure 1). Here, the optimists saw the S-S trade in sophisticated manufactures as a potential catalyst for dynamic gains aiding industrialization and technology transfer within the South (Amsden 1987; Lall 1987). Case studies within South America and Southeast Asia argued that for certain industries (e.g., industrial and automotive intermediate products), S-S trade has allowed a technological upgrading enabling middle-income Southern countries to eventually penetrate Northern markets (Heller 1976; Chudnovsky 1989). Pessimists, on the other hand, saw these exports as a legacy of inefficient import substituting industrialization (ISI) era excess capacity, whereby higher-income Southern countries "dump" low-quality, capital-intensive manufactures on less developed Southern countries (Havrylyshyn 1985). At any rate, the possibility of expansion of $\mathrm{S}-\mathrm{S}$ trade in these products remained a contentious question (Greenaway and Milner 1990).

Nevertheless, only since the mid-1980s has S-S trade grown to be a substantial force in world trade, prompting a third wave and renewed interest in its causes and effects. Between 1970 and 2003, the S-S trade in manufactures grew at an annual rate of 18.3

1. More recently, the dramatic increase of South-South (S-S) preferential trade agreements (PTAs) in the 1990s has been followed by several studies (mostly based on static models) attempting to measure their welfare effects (as of September 24, 2007, at least 50 of 194 total PTAs reported to the World Trade Organization were S-S PTAs). For example, Venables (2003) argues that the distribution of gains from S-S PTAs is likely to favor larger, more developed Southern countries, and therefore, North-South preferential trade agreements are better fit for most developing countries (for a review, see World Bank 2004). 


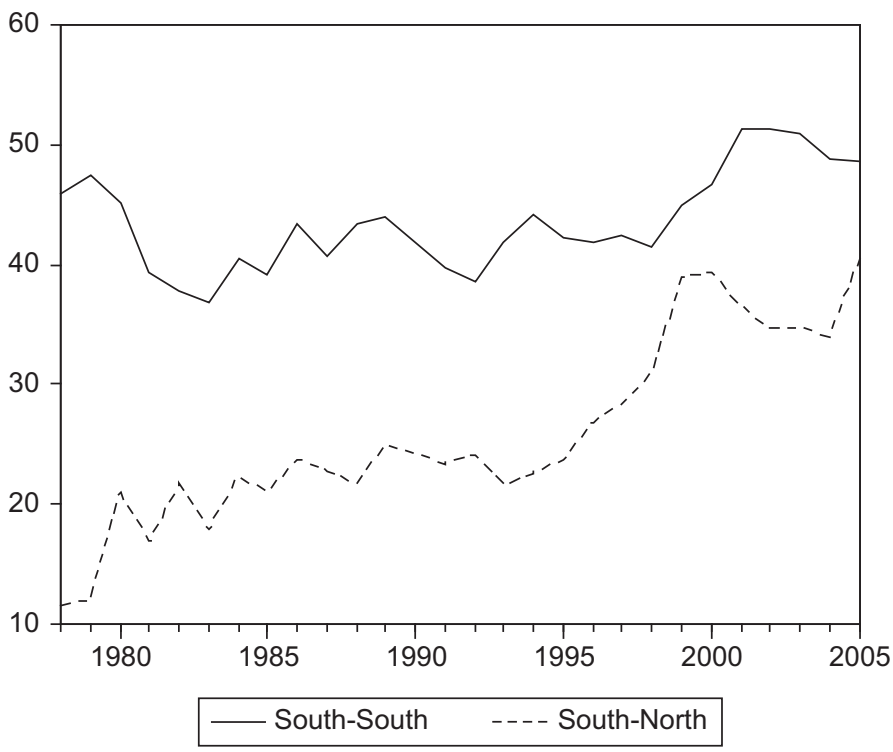

Figure I.

Sample Group: Median Share of Technology-and-Skill-Intensive Goods in Manufactures Exports to the South (South-South) and the North (South-North) (percentages)

Note: South-South and South-North represent the median share of technology-and-skill-intensive manufactures exports to the South and the North in total manufactures exports to each region, respectively.

Source: Comrades' and authors' calculations.

percent, almost twice as high as total world exports and total N-N trade. By 2003, manufactures accounted for over two-thirds of S-S merchandise exports compared to 25 percent in 1965 (United Nations Conference on Trade and Development 2005). Likewise, the share of the South in world manufactures exports increased from 5 percent in 1978 to 36 percent in 2005, while that of S-S manufactures exports reached 16 percent from a mere two percent during the same period (COMTRADE 2008). Equally impressive has been the increasing Southern share of skill-intensive manufactures in world exports of these goods that reached 35 percent in 2005 from 2 percent in 1978, with an average annual growth rate of 10 percent (COMTRADE 2008). Furthermore, more than half of Southern skill-intensive manufactures exports are destined for the South (Figure 1, Table 1). By 2001, manufactures accounted for over two-thirds of S-S merchandise exports (WTO 2003). In fact, "five out of the top ten products in S-S trade are high-technology manufactures" (United Nations Industrial Development Organization [UNIDO] 2005: 18).

\section{S-S Intra-industry Trade: Current Performance}

In this study, we focus on $\mathrm{S}-\mathrm{S}$ as well as $\mathrm{S}-\mathrm{N}$ trade in total and technology-and-skillintensive manufactures, given the previous literature's focus on possible dynamic gains from $\mathrm{S}$-S trade in capital-intensive manufactures. For twenty-eight developing countries over the time span 1978 to 2005 , we selected seventy-five commodities that fall into the 


\section{Table I}

Country Sample to Total South and World Exports (percentages)

\begin{tabular}{|c|c|c|c|c|c|c|}
\hline \multirow[b]{2}{*}{ Year } & \multicolumn{2}{|c|}{$\begin{array}{l}\text { Skill-Intensive } \\
\text { Manufactures }\end{array}$} & \multicolumn{2}{|c|}{$\begin{array}{c}\text { Total } \\
\text { Manufactures }\end{array}$} & \multicolumn{2}{|c|}{$\begin{array}{c}\text { Median Share } \\
\text { of ... Exports of the } \\
\text { Sample Going to the South }\end{array}$} \\
\hline & South & World & South & World & $\begin{array}{l}\text { Skill-Intensive } \\
\text { Manufactures }\end{array}$ & Manufactures \\
\hline 1978 & 91 & 2 & 79 & 4 & 46 & 27 \\
\hline 1979 & 92 & 3 & 80 & 5 & 53 & 33 \\
\hline 1980 & 74 & 4 & 72 & 6 & 70 & 46 \\
\hline 1981 & 77 & 4 & 77 & 7 & 65 & 49 \\
\hline 1982 & 72 & 5 & 72 & 7 & 57 & 44 \\
\hline 1983 & 78 & 6 & 78 & 9 & 55 & 42 \\
\hline 1984 & 81 & 7 & 73 & 10 & 60 & 37 \\
\hline 1985 & 79 & 7 & 70 & 10 & 63 & 41 \\
\hline 1986 & 82 & 7 & 71 & 10 & 58 & 37 \\
\hline 1987 & 87 & 9 & 79 & 13 & 53 & 35 \\
\hline 1988 & 87 & 10 & 81 & 14 & 56 & 39 \\
\hline 1989 & 82 & 11 & 78 & 15 & 52 & 38 \\
\hline 1990 & 85 & 11 & 79 & 14 & 50 & 38 \\
\hline 1991 & 95 & 12 & 93 & 16 & 55 & 41 \\
\hline 1992 & 91 & 13 & 90 & 18 & 57 & 40 \\
\hline 1993 & 93 & 16 & 90 & 20 & 57 & 40 \\
\hline 1994 & 92 & 17 & 90 & 21 & 55 & 42 \\
\hline 1995 & 91 & 19 & 89 & 22 & 53 & 43 \\
\hline 1996 & 88 & 19 & 85 & 22 & 53 & 46 \\
\hline 1997 & 88 & 20 & 85 & 23 & 52 & 44 \\
\hline 1998 & 85 & 19 & 83 & 22 & 53 & 41 \\
\hline 1999 & 87 & 20 & 85 & 23 & 46 & 39 \\
\hline 2000 & 87 & 23 & 84 & 25 & 47 & 42 \\
\hline 2001 & 85 & 23 & 82 & 25 & 50 & 42 \\
\hline 2002 & 89 & 24 & 87 & 26 & 52 & 43 \\
\hline 2003 & 85 & 25 & 83 & 27 & 52 & 45 \\
\hline 2004 & 80 & 27 & 77 & 27 & 53 & 47 \\
\hline 2005 & 81 & 28 & 79 & 29 & 58 & 50 \\
\hline Mean & 85 & 14 & 81 & 17 & 55 & 41 \\
\hline
\end{tabular}

Note: Skill-Intensive Manufactures, and Total Manufactures represent the share of sample countries in total South and World Exports of these goods respectively.

Source: Comrades' and authors' calculations.

"medium" and "high" technology classification of exports according to UNIDO (2004) (list and description of commodities available on request). ${ }^{2}$ For a comparison base, we also examined the same countries' trade in both directions in total manufactures (Table 1). The bilateral trade data in manufactures and skill-intensive manufactures are obtained from the

2. According to Lall (2000), medium-technology products "tend to have complex technologies, with moderately high levels of research and development (R\&D), advanced skill needs and lengthy learning periods." Likewise, high-technology products are those with "advanced and fast-changing technology, with high R\&D investments and prime emphasis on product design. The most advanced technologies require sophisticated technology infrastructure, high levels of specialized technical skills and close interaction between firms and universities or research institutions" (94). 
Table 2

Descriptive Statistics

\begin{tabular}{|c|c|c|c|c|c|c|c|c|c|}
\hline \multirow[b]{4}{*}{ Year } & \multirow[b]{4}{*}{$\mathrm{N}$} & \multicolumn{8}{|c|}{ Medians } \\
\hline & & \multicolumn{4}{|c|}{ Manufactures } & \multicolumn{4}{|c|}{ Technology- and Skill-Intensive } \\
\hline & & \multicolumn{2}{|c|}{ North } & \multicolumn{2}{|c|}{ South } & \multicolumn{2}{|c|}{ North } & \multicolumn{2}{|c|}{ South } \\
\hline & & Nmnxt & Nmnxy & Smnxt & Smnxy & Nskxt & Nskxy & Sskxt & Sskxy \\
\hline 1978 & 7 & 22.75 & 3.87 & 9.57 & 1.45 & 2.56 & 0.44 & 4.56 & 0.78 \\
\hline 1979 & 9 & 22.40 & 4.46 & 12.63 & 1.75 & 2.76 & 0.53 & 5.21 & 1.01 \\
\hline 1980 & 15 & 14.07 & 1.86 & 10.53 & 1.42 & 2.42 & 0.27 & 4.04 & 0.43 \\
\hline 1981 & 17 & 17.46 & 2.15 & 10.84 & 2.10 & 1.74 & 0.13 & 5.08 & 0.58 \\
\hline 1982 & 18 & 20.26 & 1.72 & 12.52 & 1.63 & 2.71 & 0.36 & 4.66 & 0.41 \\
\hline 1983 & 23 & 20.50 & 2.59 & 9.65 & 1.85 & 2.48 & 0.19 & 3.61 & 0.44 \\
\hline 1984 & 23 & 21.10 & 3.30 & 12.04 & 2.10 & 2.53 & 0.24 & 4.25 & 0.51 \\
\hline 1985 & 24 & 22.90 & 3.18 & 12.47 & 2.09 & 2.61 & 0.36 & 6.03 & 0.64 \\
\hline 1986 & 26 & 23.16 & 2.80 & 15.06 & 1.94 & 2.86 & 0.40 & 6.19 & 0.68 \\
\hline 1987 & 27 & 23.91 & 3.34 & 14.66 & 2.50 & 3.76 & 0.52 & 6.54 & 0.66 \\
\hline 1988 & 27 & 24.49 & 3.74 & 16.86 & 2.65 & 4.14 & 0.53 & 6.13 & 0.86 \\
\hline 1989 & 27 & 27.74 & 3.70 & 16.22 & 2.39 & 4.34 & 0.67 & 6.26 & 0.91 \\
\hline 1990 & 27 & 26.35 & 3.75 & 16.80 & 2.34 & 4.73 & 0.85 & 6.14 & 0.76 \\
\hline 1991 & 27 & 29.53 & 4.01 & 18.56 & 2.76 & 4.84 & 0.83 & 6.56 & 0.97 \\
\hline 1992 & 27 & 29.96 & 4.82 & 17.67 & 2.61 & 5.01 & 0.84 & 6.65 & 0.81 \\
\hline 1993 & 27 & 32.76 & 4.17 & 20.39 & 2.65 & 5.52 & 0.83 & 7.31 & 1.09 \\
\hline 1994 & 27 & 32.04 & 5.40 & 20.24 & 3.22 & 6.19 & 1.09 & 7.00 & 1.22 \\
\hline 1995 & 28 & 30.75 & 4.75 & 20.60 & 3.34 & 5.29 & 0.79 & 7.09 & 1.19 \\
\hline 1996 & 28 & 27.91 & 4.29 & 20.57 & 3.29 & 5.25 & 0.86 & 8.63 & 1.23 \\
\hline 1997 & 28 & 26.22 & 4.97 & 20.41 & 3.65 & 5.79 & 0.90 & 8.10 & 1.27 \\
\hline 1998 & 28 & 33.44 & 6.19 & 21.19 & 3.22 & 7.79 & 1.08 & 8.95 & 1.20 \\
\hline 1999 & 28 & 44.96 & 6.64 & 20.75 & 2.94 & 10.85 & 2.11 & 9.43 & 1.22 \\
\hline 2000 & 28 & 39.80 & 6.40 & 21.12 & 3.31 & 11.80 & 1.89 & 9.48 & 1.37 \\
\hline 2001 & 28 & 35.12 & 6.97 & 23.70 & 3.85 & 8.95 & 1.53 & 10.75 & 1.73 \\
\hline 2002 & 28 & 36.33 & 6.99 & 22.03 & 4.25 & 9.26 & 1.80 & 11.29 & 1.82 \\
\hline 2003 & 28 & 33.19 & 7.78 & 23.32 & 4.54 & 8.97 & 1.81 & 11.15 & 1.66 \\
\hline 2004 & 28 & 30.62 & 7.45 & 24.25 & 4.50 & 7.91 & 1.90 & 11.88 & 1.77 \\
\hline 2005 & 27 & 30.37 & 7.57 & 24.07 & 5.25 & 7.61 & 2.22 & 11.98 & 2.04 \\
\hline Mean & & 27.86 & 4.60 & 17.45 & 2.84 & 5.38 & 0.93 & 7.32 & 1.04 \\
\hline
\end{tabular}

Note: Nmnxt and Nmnxy are manufactured goods exports to the North as a share of merchandise trade and gross domestic product (GDP), respectively. Smnxt and Smnxy are manufactured goods exports to the South as a share of merchandise exports and GDP, respectively. Nskxt and Nskxy are skilled goods exports to the North as a share of merchandise exports and GDP, respectively. Sskxt and $S s k x y$ are skilled goods exports to the South as a share of merchandise exports and GDP, respectively.

Sources: World Development Indicators (World Bank n.d.), COMTRADE (2008) database, and authors' calculations.

United Nations Commodity Trade Statistics Database (COMTRADE 2008). For industrial classification, we used the Standard International Trade Classification of Commodities, Revision 2 (at the three-digit level) because it goes the furthest back in time for most Southern countries, thus allowing us the largest sample possible (UNIDO 2004).

The pattern and direction of trade we are interested in examining require the selection of those developing countries with a sufficiently diversified production structure, which 


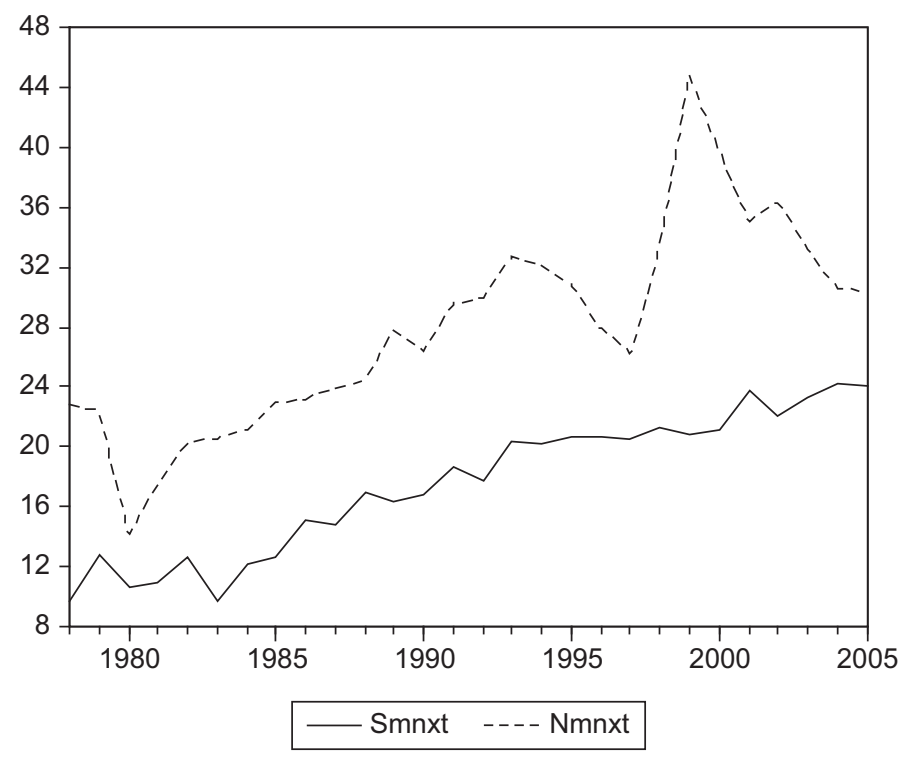

Figure 2.

Sample Group: Manufactured Goods as a Share of Merchandise Exports (medians) (percentages)

Note: Nmnxt and Smnxt are manufactured goods exports to the North and the South as a share of merchandise exports, respectively.

export such commodities in all directions. As a result, we have selected twenty-eight developing countries that, on average, account for 81 percent of total manufactures and 85 percent of technology-and-skill-intensive manufactures exports from the South and 76 percent of all S-S manufactures exports between 1978 and 2005 (Tables 1 and 2). ${ }^{3}$ During the period analyzed, we observe a steady increase in the share of these countries in total world exports of total manufactures and technology-and-skill-intensive manufactures, reaching from 2 percent and 4 percent in 1978 to 28 percent and 29 percent in 2005, respectively (Table 1). Although the country sample is biased toward middle-income countries, part of the interest in S-S trade has been examining such trade as a conduit for changing a country's comparative advantage into more sophisticated exports.

In terms of the pattern and direction of trade in our sample, we see an increase in S-S trade compared to S-N trade in both total and technology-and-skill-intensive manufactures. Accordingly, the median share of manufactures and technology-and-skill-intensive manufactures exports to the South (in total exports of these goods from sample countries) increased from 27 percent and 46 percent in 1978 to 50 percent and 58 percent in 2005, respectively (Table 1). From Figure 1, we also see a higher skill content of manufactures

3. The sample includes Algeria, Argentina, Bolivia, Brazil, Chile, China, Colombia, Costa Rica, Ecuador, Egypt, Hong Kong, India, Indonesia, Jordan, Korea, Malaysia, Mexico, Morocco, Pakistan, Paraguay, Philippines, Singapore, Syria, Thailand, Tunisia, Turkey, Uruguay, and Venezuela. The Northern countries include high-income Organization for Economic and Cooperation and Development countries, while the South includes all low- and middle-income countries. 


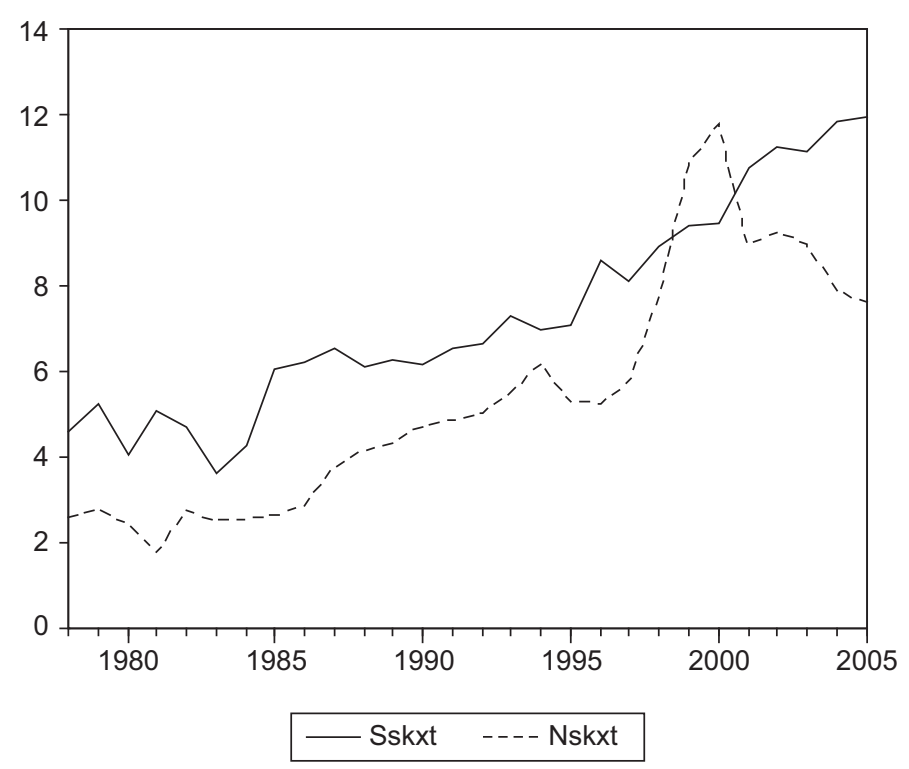

Figure 3.

Sample Group: Skilled Goods Exports as a Share of Merchandise Trade (medians) (percentages) Note: Nskxt and Sskxt are skill-intensive manufactures exports to the North and the South as a share of merchandise exports, respectively.

exports in S-S trade than S-N trade. Accordingly, while the average median share of skillintensive goods in total manufactures exports is 44 percent in S-S trade, it is 26 percent in S-N trade between 1978 and 2005. However, we also observe that the skill content of S-N exports (i.e., share of technology-and-skill-intensive manufactures in total manufactures exports) has been increasing at a much faster rate, with an annual average of 4.7 percent compared to a mere 0.2 percent in S-S exports.

Furthermore, the median share of manufactures exports to the North in total Southern merchandise exports (and in gross domestic product [GDP]) increased from around 23 percent (3.9 percent) in 1978 to 30 percent ( 7.6 percent) in 2005, while those to the South increased from around 9.6 percent (1.5 percent) to 24 percent (5.3 percent) (Table 2). Similarly, the median share of technology-and-skill-intensive manufactures exports to the North in total Southern merchandise exports (and in GDP) increased from around 2.6 percent ( 0.4 percent) in 1978 to 7.6 percent (2.2 percent) in 2005, while those to the South increased from around 4.6 percent ( 0.8 percent) in 1978 to 12 percent ( 2 percent) in 2005 (Table 2 and Figures 2 and 3).

\section{Analysis and a Proposed S-S Trade Research Agenda}

Figure 4 shows that up until the late 1990s, S-S intra-industry trade in technology-andskill-intensive manufactures was consistently higher than the S-N trade. Moreover, a regional breakdown (not shown) shows S-S intra-industry trade higher once China and Southeast Asian countries are excluded. This high intra-industry trade suggests possible 


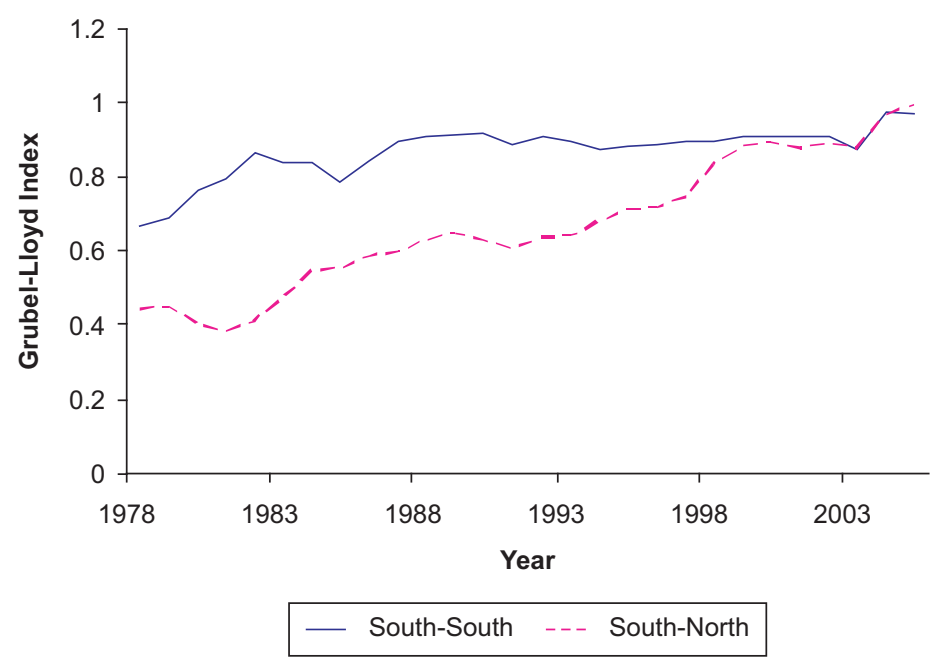

Figure 4. Sample Group: Intra-industry Trade in Skill-Intensive Goods
Note: Grubel-Lloyd index $=1-\frac{\sum_{i=1}^{n}\left|X_{i}-M_{i}\right|}{\sum_{i=1}^{n}\left|X_{i}-M_{i}\right|}$, where $X=$ exports, $M=$ imports, and $i=$ skill-intensive' manufatures (Grubel and Lloyd 1975).

dynamic gains and technology transfer within the South as well as technological upgrading (since S-N intra-industry trade is catching up) over time. Nevertheless, despite the remarkable growth in S-S trade and its increasingly industrialized nature (Figures 1, 2, and 3), it remains significantly lower than S-N and North-North (N-N) trade. Accordingly, S-S trade represents 15 percent of global trade compared to over 50 percent for N-N and 35 percent for S-N trade (United Nations Conference on Trade and Development 2005). In addition, the distribution of this trade is highly skewed and is driven mostly by emerging markets, with a few "semiperipheral" countries capturing a greater proportion of S-S trade (Table 1). Moreover, production sharing and other triangular trade whose ultimate destination is developed countries are likely to account for a portion of such trade.

The presence of structural barriers to S-S trade requires further investigation. First, average tariffs in the South are higher on other developing country imports than those on developed countries. Second, similarity in production pattern and resource base makes export substitutes. ${ }^{4}$ Third, infrastructural deficiencies, including financial sector development as well as insurance, transportation, and other logistical problems, limit S-S trade. Furthermore, in terms of export diversity, unlike our sample of emerging markets, twothirds of developing countries depend on primary commodities for 50 percent or more of their export earnings (United Nations Conference on Trade and Development 2005).

4. However, according to the United Nations Industrial Development Organization (2005) and Amsden (1987), this enables appropriate technology transfer. 
Regarding the future of S-S trade, the suggestions by recent literature (WTO 2003) of simple trade and financial liberalization within the South, especially by less developed Southern countries, may not be the most efficient route for technology transfer within the South, especially for low-income developing countries. Rather, technology transfer agreements, licensing, or other institutionalized methods may be more appropriate, especially given the large gap in technological development that already exists within the global South. As WTO laws proscribe or limit traditional industrial policy, special care must be taken along regional or international lines in supporting S-S trade. Along those lines, recent efforts such as IBSA (between India, Brazil, and South Africa) are promising and can be extended to other countries within the global South to complement traditional S-S cooperation, such as within the United Nations Conference on Trade and Development.

Further research also needs to be done in exploring (1) the barriers to S-S trade and S-S technological spillovers; (2) the effects of S-S foreign direct investment (WTO 2003); (3) the political economic analysis of S-S trade agreements, including the possibility of alternative agreements, which can include industrial and technical cooperation (closer to what early advocates of S-S integration, such as Myrdal (1956), had in mind); and finally, (4) whether dependence effects of Northern growth on Southern growth changes as S-S linkages increase (Hoffmaister, Samiei, and Pradhan 1998).

\section{References}

Amsden, A. H. 1987. The directionality of trade: Historical perspective and overview. In World Bank symposium exports of developing countries: How direction affects performance, ed. O. Havrylyshyn, 123-38. Washington, DC: World Bank.

Chudnovsky, D.1989. South-South trade in capital goods: The experiences of Argentina and Brazil. In SouthSouth trade: Trends, issues, and obstacles to its growth, ed. V. Ventura-Dias, 216-48. New York: Praeger.

COMTRADE. 2008. United Nations commodity trade statistics database. http://comtrade.un .org/db/ (accessed May 12, 2008).

De Silva, L. 1983. The non-aligned movement: Its economic organization and NIEO perspectives. In The challenges of South-South cooperation, ed. B. Palvic, R. Uranga, B. Cizelj, and M. Svetlicic, 76. Boulder, CO: Westview.

Greenaway, D., and C. Milner. 1990. South-South trade: Theory, evidence, and policy. World Bank Research Observer 5 (1): 47-68.

Grubel, H. G., and Lloyd, P. J. 1975. Intra-industry trade: The theory and measurement of international trade in differentiated products. New York: John Wiley.

Havrylyshyn, O. 1985. The direction of developing country trade: Empirical evidence of differences between South-South and South-North trade. Journal of Development Economics 19 (3): 255.

Heller, P. S. 1976. Factor endowment change and comparative advantage: The case of Japan. Review of Economics and Statistics 58 (3): 283-92.

Hoffmaister, A. W., H. Samiei, and M. Pradhan. 1998. Have North-South linkages changed? World Development 26 (5): 791-808.

Iike, K. 1988. Third world solidarity: The Group of 77 in the United Nations General Assembly. International Organization 4 (2): 375-95.

Lall, S. 1987. India's economic relations with the South. In World Bank symposium exports of developing countries: How direction affects performance, ed. O. Havrylyshyn, 109-20. Washington, DC: World Bank.

. 2000. The technological structure and performance of developing country manufactured exports, 1985-1998. Oxford Development Studies 28 (3): 337-70. 
Lewis, W. A. 1980. The slowing down of the engine of growth. American Economic Review 70 (3): 555-64.

Morphet, S. 2004. Multilateralism and the non-aligned movement: What is the global South doing and where is it going? Global Governance 10 (4): 517-37.

Myrdal, G. 1956. An international economy. London: Routledge and Kegan Paul.

Narlikar, A. 2006. Fairness in international trade negotiations: Developing countries in the GATT and WTO. The World Economy 29 (8): 1005-29.

Narlikar, A., and R. Wilkinson. 2004. Collapse at the WTO: A Cancun post-mortem. Third World Quarterly 25 (3): 447-60.

Orlov, A. 2002. The non-aligned movement: 40 years after. International Affairs: A Russian Journal of World Politics, Diplomacy \& International Relations 48 (1): 49-56.

Prashad, V. 2006. The darker nations: A people's history of the Third World. New York: New Press.

Sridharan, K. 1998. G-15 and South-South cooperation: Promise and performance. Third World Quarterly 19 (3): 357-73.

United Nations Conference on Trade and Development. 2005. Some key issues in South-South trade and economic cooperation. New York: United Nations.

United Nations Industrial Development Organization. 2004. Industrial development report. New York: United Nations.

- 2005. Industrial development, trade and poverty alleviation through South-South cooperation. New York: United Nations.

Venables, A. 2003. Winners and losers from regional integration agreements. The Economic Journal 113: 747-61.

Wardaya, B. 2005. Global solidarity against unilateralism. Inter-Asia Cultural Studies 6 (4): 476-86.

Willets, P. 1978. The non-aligned movement: The origins of a Third World alliance. London: Pinter.

World Bank. 2004. Global economic prospects 2005: Trade, regionalism and development. Washington, DC: World Bank.

World Bank. n.d. World development indicators database. Available at http://www.worldbank.org/data/ (accessed May 12, 2008).

World Trade Organization. 2003. World trade report. Geneva: WTO Publications.

Omar S. Dahi is an assistant professor of economics at Hampshire College. His research and teaching interests are in the areas of economic development and international trade, with a special focus on South-South economic cooperation, and the political economy of the Middle East and North Africa.

Firat Demir is an assistant professor of economics at the University of Oklahoma. His research is focused on international finance and development economics and in particular on the role of globalization of financial markets in determining the growth and development path followed by developing countries. His most recent publications include "Financial Liberalization, Private Investment and Portfolio Choice: Financialization of Real Sectors in Emerging Markets" (Journal of Development Economics, forthcoming) and "Volatility of Short-term Capital Flows, Financial Anarchy and Private Investment in Emerging Markets" (Journal of Development Studies, forthcoming). 